\title{
Pattern of Facial Laceration in Suburban Plastic Surgery Practice
}

Emmanuel E Esezobor ${ }^{1 *}$, Godwin Obasikene ${ }^{1}$, Gold O Amuwha ${ }^{2}$, Efosa MA Ukponmwan ${ }^{1}$ and Eromosele Airewele ${ }^{1}$

${ }^{1}$ Department of Surgery, Irrua Specialist Teaching Hospital, Irrua, Edo State, Nigeria

${ }^{2}$ Department of Oral and Maxillofacial surgery, Irrua Specialist Teaching Hospital, Irrua, Edo State, Nigeria

\begin{abstract}
Background: The face is a relevant part of the body which serves as a tool for identification. As man goes through the rigors of life, it is at risk of injuries. The effect of these injuries and the outcome of its management can affect the socioeconomic and psychological status of these patients.
\end{abstract}

Aim: To know those at risk of facial laceration and the part of the face that is most affected.

Method: We carried out a clinical audit of patients managed for facial Laceration in Irrua Specialist Teaching Hospital, Irrua Edo State, Nigeria from January 2008 to December 2011.

Statistical analysis used: SPSS

Result: There were 353 patients who had facial laceration as the main injury or part of their multiple injuries. Male to female ratio of those affected is 2.6: 1. Patients in the third decade of life are most affected followed by those in the first decade. Road traffic accident is the commonest aetiological factor.

Conclusion: Facial laceration affects mostly the working class and students in higher institution. The part harboring the aesthetic features of the face is as vulnerable as the other part of the face. They are preventable.

Keywords: Facial laceration; Aesthetics; Preventable

\section{Introduction}

Laceration to the facial skin is commonly encountered in the care of the traumatized patient. They could occur in isolation, extend deep to involve the deeper soft tissues and even deeper to involve the facial skeleton. The injury could be in association with other more pressing systemic injury. While attention is devoted to the bony injuries, there could be less attention to details in handling these facial lacerations leading to unsatisfactory scar. This study seeks to know those who are affected by facial lacerations, their common causes and the distribution in relation to the facial bone injuries and the aesthetic features of the face.

\section{Patients and Method}

This is a retrospective study of facial laceration presenting to the emergency room in Irrua Specialist Teaching Hospital, Irrua Edo State in Nigeria between January 2008 and December 2011. The medical records of the patients were manually retrieved for demographic characteristics and etiology. Using the neoclassical Canons, the faces were divided into three (3) equal proportions namely the upper, mid and lower face. This was achieved with horizontal lines drawn at the trichion (hairline), glabella, subnasale (root of the nose) and gnathion (chin). The regions of the face affected by laceration injuries were documented. This information were analysed using SPSS for window (version 16.0 SPSS Inc, Chicago, IL) statistical software package and presented in a tabular and descriptive form. The test of significance was analysed using ANOVA and differences were considered significant at $\mathrm{p}<0.05$.

\section{Result}

A total of 353 patients were seen within this period of which $72 \%$ $(n=254)$ were male and $28 \%(n=99)$ were females (Table 1). Male to female ratio was $2.6: 1$. The age group mostly affected is those within 21-30 years accounting for $42.8 \%(n=151)$, followed by those between 1-10 years accounting for $17.3 \%(n=61)$ of the cases. Other age group accounted for the remaining percentage (Table 2 and Figure 1). The commonest etiology was road traffic accident which accounted for $51.0 \%(n=180)$ followed by assault which accounted for $20.7 \%(n=73)$ (Table 3 and Figure 2). There is a statistical significance difference $(\mathrm{p}=0.000)$ in the number of the facial laceration from RTA when compared with other causes of facial laceration.

\begin{tabular}{|c|c|c|c|}
\hline & & Frequency & Percent \\
\hline Valid & Male & 254 & 72.0 \\
\hline & female & 99 & 28.0 \\
\hline & Total & 353 & 100.0 \\
\hline
\end{tabular}

Table 1: Sex Distribution.

\begin{tabular}{|c|c|c|}
\hline & Frequency & Percent \\
\hline $1-10$ & 61 & 17.3 \\
\hline $11-20$ & 37 & 10.5 \\
\hline $21-30$ & 151 & 42.8 \\
\hline $31-40$ & 48 & 13.6 \\
\hline $41-50$ & 31 & 8.8 \\
\hline $51-60$ & 13 & 3.7 \\
\hline $61-70$ & 6 & 1.7 \\
\hline $71-80$ & 6 & 1.7 \\
\hline Total & 353 & 100.0 \\
\hline
\end{tabular}

Table 2: Age Distribution.

*Corresponding author: Emmanuel Ehizome Esezobor, Irrua Specialist Teaching Hospital, P.M.B 8 Irrua, Edo State, Nigeria, Tel: +2347035176690; E-mail: ehizome@yahoo.com

Received December 06, 2013; Accepted December 28, 2013; Published December 30, 2013

Citation: Esezobor EE, Obasikene G, Amuwha GO, Ukponmwan EMA, Airewele E (2013) Pattern of Facial Laceration in Suburban Plastic Surgery Practice. J Trauma Treat 3: 180. doi:10.4172/2167-1222.1000180

Copyright: (c) 2013 Esezobor EE, et al. This is an open-access article distributed under the terms of the Creative Commons Attribution License, which permits unrestricted use, distribution, and reproduction in any medium, provided the original author and source are credited. 
Citation: Esezobor EE, Obasikene G, Amuwha GO, Ukponmwan EMA, Airewele E (2013) Pattern of Facial Laceration in Suburban Plastic Surgery Practice. J Trauma Treat 3: 180. doi:10.4172/2167-1222.1000180

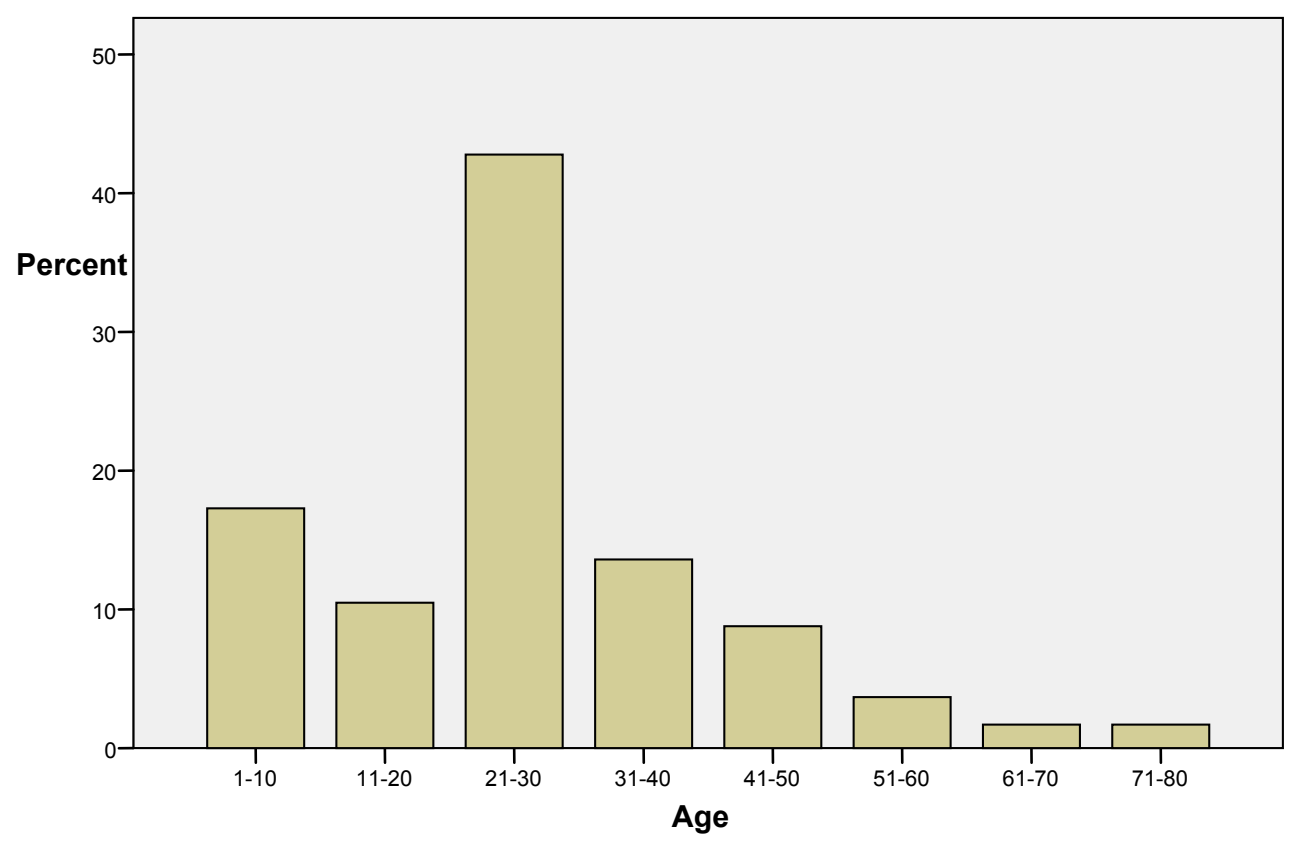

Figure 1: Age distribution of patients seen with facial lacerations.

\begin{tabular}{|c|c|c|}
\hline Cause of Facial Laceration & Frequency & Percent \\
\hline assault & 73 & 20.7 \\
\hline RTA & 180 & 51.0 \\
\hline domestic & 20 & 5.7 \\
\hline occupational & 33 & 9.3 \\
\hline fall & 47 & 13.3 \\
\hline Total & 353 & 100.0 \\
\hline
\end{tabular}

Table 3: Causes of Facial laceration.

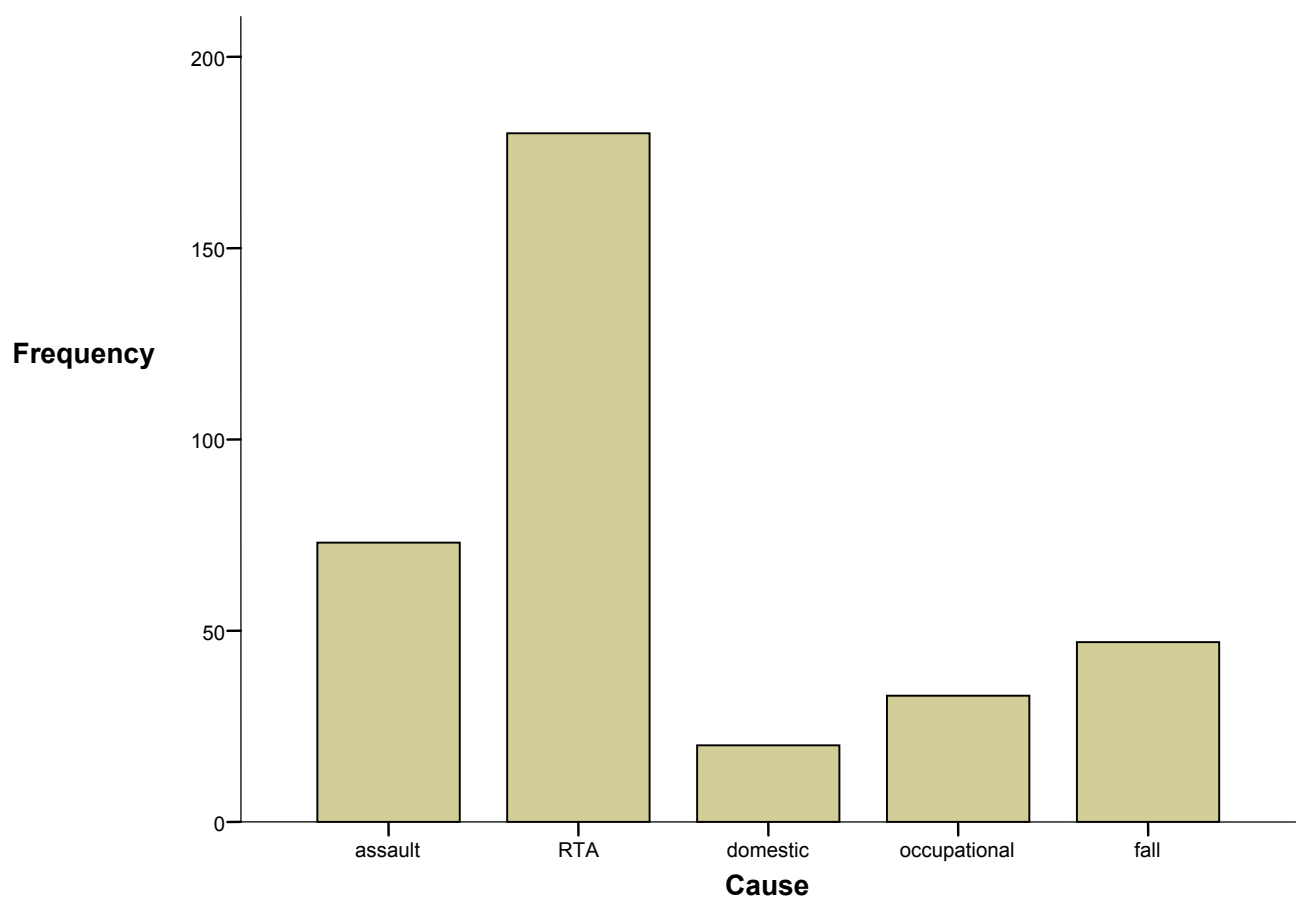

Figure 2: Causes of Facial laceration. 
Fall was found to be the commonest aetiology in children of age ten and below, constituting $50.0 \%$ of the sixty-one patients within this age bracket. Though there is no statistical significance difference $(\mathrm{p}=0.058)$ in the distribution of facial injuries seen in the number of the facial laceration on the upper, middle and lower face, the middle face was found to be most affected by facial laceration, accounting for $46.5 \%$ $(n=164)$ of the cases seen. This is closely followed by the lower face which accounted for $41.9 \%(n=148)$ of the cases seen. The upper face is the area least affected and is involved in $11.6 \%(n=41)$ of cases (Table 4 and Figure 3).

\section{Discussion}

Many of the soft tissue injuries seen in trauma patient are simple lacerations that required nothing more than suturing [1]. Hitosuqi et al. conducted a study in Japan and found out that most common maxillofacial injury from road traffic accident is lacerations [2]. When the face is the part of the body presented with laceration injury, proper attention to the aesthetic outcome after repair becomes of paramount concern. The underlying structures may be involved in the injury which may require the necessary repair, but the outcome of the skin cover may live to tell a good or bad tale.

Laceration injuries to the face affect all sexes and ages but our study revealed higher incidence in males. This is in line with other studies done on similar subject [3-8]. Furthermore, our study found a male to female ratio of 2.6:1 which is in keeping with studies done in Ibadan, southern Nigeria, South Africa, United state of America and United
Kingdom $[3,5,6]$. However, studies from Northern Nigeria, Egypt and Sudan revealed a wider male to female ratio of between 3:1 to 5.5:1 $[4,7,8]$. This can be explained by the limited outgoing role expected of women by the Islamic religion playing a vital role in reducing their exposure to facial injuries.

The working class group and students in higher institutions in their third decade of life are the most vulnerable. This finding is also consistent with other studies on facial injuries $[8,9]$. This could be explained from the fact that these groups consist of the very active labour that are prone to trauma generally. It is also noted that this study took place in Irrua which is close to the University town of Ekpoma with its teeming population of students. A common cause of road crashes in this community is motorcycle crashes and students are a common risk group [10].

Age group ten and below are the second most vulnerable group in this study. They are the preschool children who are just learning how to walk and the primary school children who love to play. The major cause of their injury is fall and our observation revealed a preponderance of lower face lacerations.

This study identifies motor vehicular crash as the commonest cause of facial laceration followed by assault. In most developed countries, assault has replaced vehicle collisions as the main cause of maxillofacial trauma; however, in many developing countries, road traffic accidents remain the major cause [11]. Several reasons have been adduced for decline in facial trauma in vehicular crashes in developed countries

\begin{tabular}{|c|c|c|}
\hline & Frequency & \\
\hline Upper face & 41 & 11.6 \\
\hline Mid face & 164 & 46.5 \\
\hline Lower face & 148 & 41.9 \\
\hline Total & 353 & 100.0 \\
\hline
\end{tabular}

Table 4: Distribution of facial injuries.

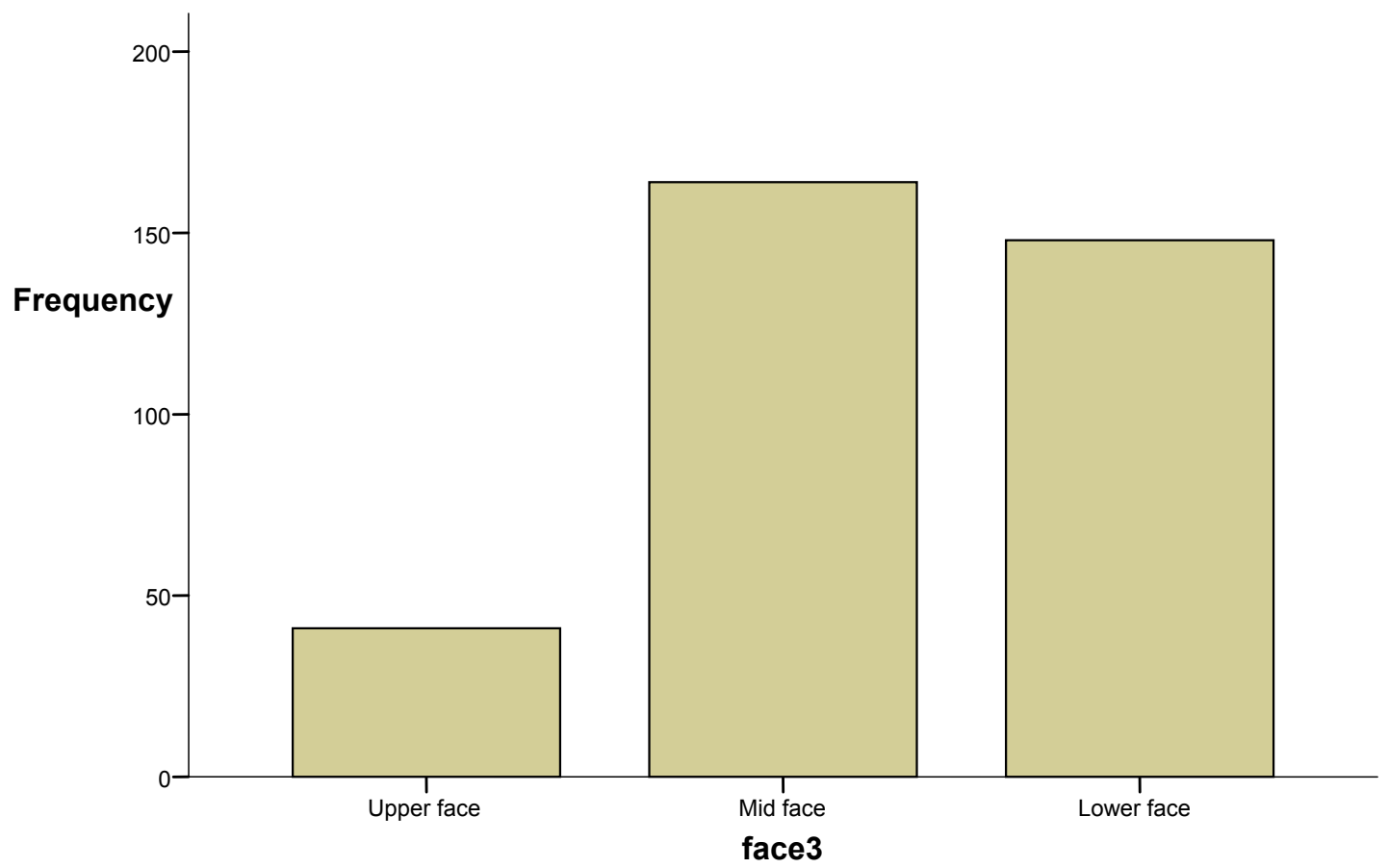

Figure 3: Part Distribution Facial Laceration. 
Citation: Esezobor EE, Obasikene G, Amuwha GO, Ukponmwan EMA, Airewele E (2013) Pattern of Facial Laceration in Suburban Plastic Surgery Practice. J Trauma Treat 3: 180. doi:10.4172/2167-1222.1000180

$[12,13]$ But the face is especially susceptible when protective devices like seat belt in vehicles and crash helmets in motorcycles are not used. Enforcement of traffic laws in many Nigerian towns have been known to be poor [14] leaving many prone to injuries of the face using the neoclassical canons introduced by artists of the Renaissance such as Leonardo da Vinci, Albrecht Durer and Cennino Cennini, our study revealed that facial lacerations commonly affect the mid and the lower face $[13,15-17]$, however, there is no statistical significance difference $(\mathrm{p}=0.058)$ in the distribution of facial injuries seen in number of the facial laceration on the upper, middle and lower face.

Previous series done on similar subject revealed a $\mathrm{T}$ distribution of facial injury [18-20]. This includes the forehead up to the anterior parietal region being the cross of the $\mathrm{T}$ while the nasal region and the lips is the stem. Our finding clearly highlights that facial injuries affect the area where the aesthetic and the unique features of the face are found. Literature review on the distribution of the injured facial bone seen in most trauma unit revealed a higher incidence of nasal, maxillary and mandibular fracture which clearly corresponds to the common distribution of facial lacerations as seen in our study [21-23]. Reasons for this observation may be because the middle and lower face are usually the area on contact with the steering wheel, the dash board or the back of the seat in cases of accidents. From the side view, the nose and the lips are the most projecting structure on the face thus increasing the chances of lacerations in these areas (Figures 4-8).

In cases of assault which are intentional, the aim of the assailants

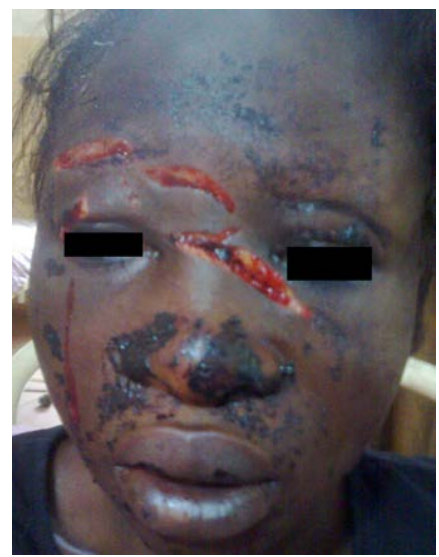

Figure 4: Showing facial laceration to the nose glabella and right brow from assault.

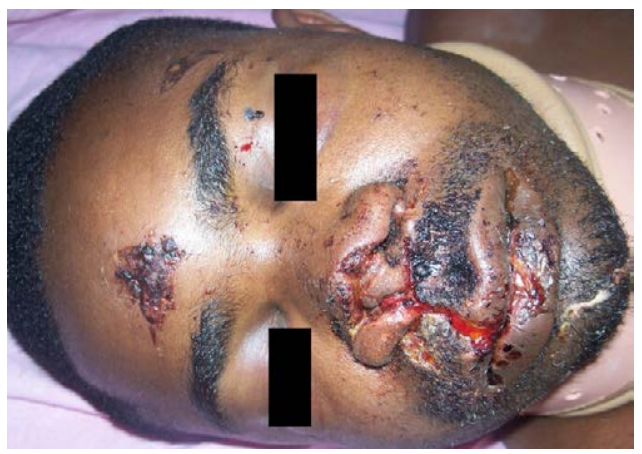

Figure 5: Showing facial laceration from RTA.

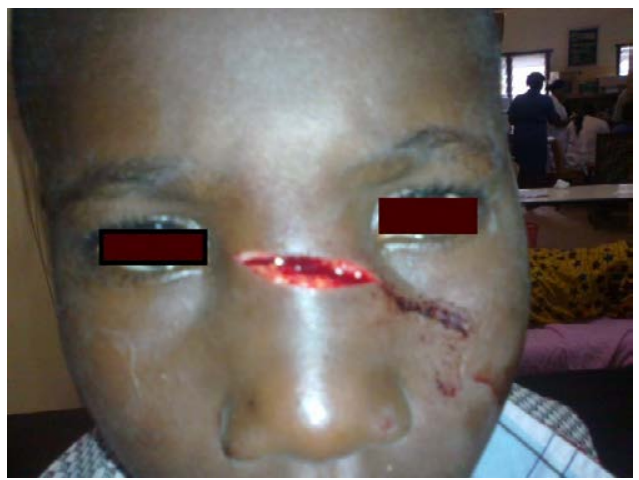

Figure 6: Showing facial laceration from fall.

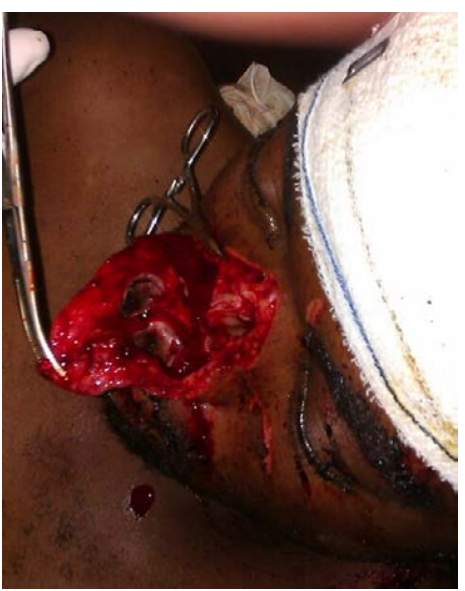

Figure 7: showing near amputation of the nose from RTA.

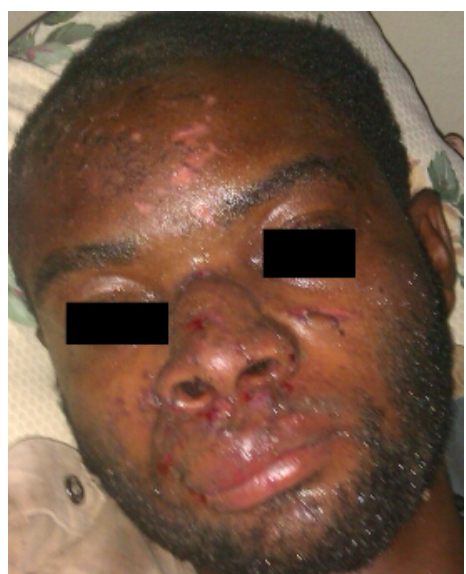

Figure 8: Showing post repair of nose in fig 7.

is to disfigure their victims. Just as in the days of old when the vicious bands of marauder in India mutilated the nose as a method of visible and lasting humiliation, so is the intention of the present day assailants in cases of assault. This can be achieved if the aesthetic features like the nose, the eyes and the lips which are found right in the centre of the face are injured. These features form the identity of humans and their distortion can have great psychosocial effect. 
Citation: Esezobor EE, Obasikene G, Amuwha GO, Ukponmwan EMA, Airewele E (2013) Pattern of Facial Laceration in Suburban Plastic Surgery Practice. J Trauma Treat 3: 180. doi:10.4172/2167-1222.1000180

Page 5 of 5

The lesson from this study is that those within the job seeking age group are most affected by this injury. Disfigured face can affect employability. Strict enforcement of the traffic law will go a long way to save the faces of this group of people. In cases of assault, facial laceration severe enough to cause permanent disfigurement should be regarded as criminal and the assailant appropriately punished. Children should be supervised during play so as to reduce the incidence of injuries and in extension, facial laceration. Lastly, it is of great advantage to the patient if the care givers are properly grounded in the repair of facial lacerations. If this cannot be guaranteed, there should be no hesitation in referring to the nearest plastic surgery unit for proper repair.

\section{Conclusion}

Facial laceration is a common injury which affects mostly the area harboring the aesthetic features of the face. Human factors play a major role in the aetiology of the injury and are largely preventable. Poor attention to their repair can change the identity of a person.

\section{Acknowledgement}

We acknowledge the contribution of all members the department of surgery, Irrua Specialist Teaching Hospital for their support.

\section{References}

1. Mueller RV (2006) Facial trauma: Soft tissue injury. In: Mathes SJ, editor. Plastic Surgery. 2nd edn. Philadelphia: Saunder Elsevier 31.

2. Hitosugi M, Mizuno K, Nagai T, Tokudome S (2011) Analysis of maxillofacial injuries of vehicle passengers involved in frontal collisions. J Oral Maxillofac Surg 69: 1146-1151.

3. Bankole OO, Fasola AO, Denloye OO (2004) Oro-facial soft tissue injuries in Nigerian children: a five-year review. Afr J Med Med Sci 33: 93-97.

4. Adebayo ET, Ajike OS, Adekeye EO (2003) Analysis of the pattern of maxillofacial fractures in Kaduna, Nigeria. Br J Oral Maxillofac Surg 41: 396400.

5. Singer AJ, Thode HC Jr, Hollander JE (2006) National trends in ED lacerations between 1992 and 2002. Am J Emerg Med 24: 183-188.

6. Islam S, Ansell M, Mellor TK, Hoffman GR (2006) A prospective study into the demographics and treatment of paediatric facial lacerations. Pediatr Surg Int 22: 797-802.

7. Hassan NA, Kelany RS, Emara AM, Amer M (2010) Pattern of craniofacial injuries in patients admitted to Tanta University Hospital--Egypt. J Forensic Leg Med 17: 26-32.
8. Elawad AHM , Ahmed OM, Saeed A, Mahgoub A (2012) Facial injuries in Khartoum State. Khartoum Medical Journal 5: 688-693.

9. Ugboko VI, Odusanya SA, Fagade OO (1998) Maxillofacial fractures in a semiurban Nigerian teaching hospital. A review of 442 cases. Int J Oral Maxillofac Surg 27: 286-289.

10. Dongo AE, Kesieme EB, Eighemherio A, Nwokike O, Esezobor E, et al (2013) Motorcycle Related Injuries among Rural Dwellers in Irrua, Nigeria: Characteristics and Correlates. Emerg Med Int 2013: 569103.

11. Adeyemo WL, Ladeinde AL, Ogunlewe MO, James O (2005) Trends and characteristics of oral and maxillofacial injuries in Nigeria: a review of the literature. Head Face Med 1: 7

12. Hunt JP, Weintraub SL, Wang YZ, Buechter KJ (2003) Kinematics of trauma". In Moore EE, Feliciano DV, Mattox KL, editors. Trauma. 5th edition. McGrawHill: Professional 149.

13. Shapiro AJ, Johnson RM, Miller SF, McCarthy MC (2001) Facial fractures in a level I trauma centre: the importance of protective devices and alcohol abuse. Injury 32: 353-356.

14. Arosanyin GT, Olowosulu AT, Oyeyemi GM (2012) Compliance with Road Safety Regulations Among Commercial Motorcyclists in Nigeria. Canadian Social Science 8: 92-100.

15. Kolar JC (1991) Anthropological guidelines for aesthetic craniofacial surgery. In Ousterhout DK. editor: Aesthetic Contouring of the craniofacial Skeleton. edn, Boston: Little Brown 15-29.

16. Vegter F, Hage JJ (2000) Clinical anthropometry and canons of the face in historical perspective. Plast Reconstr Surg 106: 1090-1096.

17. Farkas LG, Kolar JC (1987) Anthropometrics and art in the aesthetics of women's faces. Clin Plast Surg 14: 599-616.

18. Hussain K, Wijetunge DB, Grubnic S, Jackson IT (1994) A comprehensive analysis of craniofacial trauma. J Trauma 36: 34-47.

19. Key SJ, Thomas DW, Shepherd JP (1995) The management of soft tissue facial wounds. Br J Oral Maxillofac Surg 33: 76-85.

20. Koonin AJ (1973) Findings in 300 patients with facial lacerations. Plast Reconstr Surg 52: 525-529.

21. Motamedi MH (2003) An assessment of maxillofacial fractures: a 5-year study of 237 patients. J Oral Maxillofac Surg 61: 61-64.

22. Dimitroulis G, Eyre J (1991) A 7-year review of maxillofacial trauma in a central London hospital. Br Dent J 170: 300-302.

23. Bamjee Y, Lownie JF, Cleaton-Jones PE, Lownie MA (1996) Maxillofacia injuries in a group of South Africans under 18 years of age. Br J Oral Maxillofac Surg 34: 298-302. 